\title{
The Integration of Information Technology into Language Teaching
}

\author{
Xin Tang \\ Foreign Languages Department, Beijing Institute of Petrochemical Technology, Beijing, 102617, China \\ Weiran Zhang \\ Foreign Languages Department, Beijing Institute of Petrochemical Technology, Beijing, 102617, China

\begin{abstract}
English classroom is one of the orientations of current college English teaching reform. This thesis discusses the integration of information technology into college English curriculum from the ecological perspective so as to offer some advice for the practice of college English reform.
\end{abstract}

Index Terms-information technology, college English curriculum, ecologicalize, integration, college English teaching reform

\section{INTRODUCTION}

Any technology may cause huge changes in a certain field if any technology was introduced to it. And it was proved that the web-based information technology brought great changes in the field of education. After information technology was introduced into the language teaching, the traditional information delivery channel, the teaching contents, the forms of integration and even the teaching process have changed dramatically. In order to facilitate the college English teaching reform and meet the needs of qualified personnel of the country and the society, the Higher Education Department of the Ministry of Education promulgated the revised College English Curriculum Requirements (hereinafter referred to as Requirements) in 2007 on the basis of college English teaching practice and the objectives of college English reform. The Requirements (Ministry of Education, 2007) indicates that each college and university is supposed to take good advantage of modern information technology and introduce the computer-and-classroom-based English teaching mode to improve the traditional teacher-based one. The new mode is to be supported by modern information technology, especially the web to make for the orientation of individualization and autonomy free from the restriction of time and place.

In allusion to the Requirements (Ministry of Education, 2007) Professor Jianlin Chen and Gu (2008) gave the following interpretation: "the teaching concept is supposed to be internationalized the multimedia-based teaching normalized and the teaching environment ecologicalized"(p.44). Meanwhile, he put forward that "the reform of ecological college English curriculum system is the vital part of college English teaching reform and also the orientation of college English classroom teaching reform" (p.47). The foreign languages teaching changed dramatically and the traditional foreign languages were impacted greatly after the information technology was introduced into foreign languages curriculum. In this process a good many maladjustment and imbalance appeared. It is how to make it back to balance and how to integrate information technology into foreign languages really and truly that is the critical issue which should be resolved. It is pressing to study these issues under such circumstances.

\section{ECOLOGY AND COLLEGE ENGLISH TEACHING}

\section{A. Ecology and Education}

The Germany ecologist Haeckel put forward the concept of "Ecology" on the basis of Darwin's evolutionism in 1866. Then the British ecologist Tansley advanced "Ecological System". Till 1966, the American educationist Ashby brought forward "Higher Educational Ecology" in his book and firstly studied higher education from the perspective of ecology. Later the American Lawrence Cremin put forward "Ecology of Education" in Public Education in 1976 and studied the educational phenomenon with the basic ecological principles and methods; a new study field was formed accordingly. However, the study of ecological education is at the beginning stage in China (Ma, 2010).

From this perspective, the college class is a micro-ecological system which can be called classroom ecosystem. It is composed of the environment of the classroom which includes physical, social and other compound ecological factors and the niches of the class; they interact with each other and formed the basic system. The physical classroom environment mainly consists of the facilities, decorations, lights, smell, noise and comfort; the social environment consists of the arrangements of seats, the percentage of genders, the quantity of class, the relationship between teachers and students and the campus language factors and so on. As the main niches, the teachers and students interact with these environments and formed the relatively stable ecological system. After the integration of information technology, this balance is destroyed to some degree; great efforts should be made to make it back to balance again. 


\section{B. Ecology and College English Teaching}

From the perspective of ecology, the niche (teaching factors) can achieve harmony with the environment when it finds a right place in the ecology system after it possess a position in space which is most suitable for survival. That's to say, the system can achieve dynamic balance when all the niches find the right dynamic places.

At present the ecology system of college English teaching inevitably emerge imbalance because of the integration of information technology into the college English curriculum which leads to disharmony and rejection. The questions that the college English teachers in the twenty-first century are supposed to answer are how to overcome the system imbalance and negative influence under the integrated conditions and how to make the ecological system of college English teaching achieve the dynamic ecological harmony again (Chen, 2004).

\section{THE STRATEGIES OF INTEGRATION}

The teaching factors of the traditional college English curriculum have found the most suitable place in the teaching ecological system after a long-term teaching practice and inspection and formed a relatively balanced and stable ecological system of college English curriculum. Some elementary teaching factors are bound to be replaced by the new ones after the integration of information technology into college English curriculum which inevitably lead to the changes of the ecological system of college English curriculum and the influence to the balance of the original ecological system (Zhao, 2009).

After the integration of college English teaching into information technology, the teaching objectives focus on the cultivation of students' ability of language application, especially that of listening and speaking but not the cultivation of reading ability, the input and acquisition of knowledge; the teaching method is multi-dimensional and individualized but not the traditional grammar-translation, intensive reading of the texts and imitation, more attention is paid to the integration of classroom teaching into the information technology, the active students-centered classrooms, outside class knowledge constructions and so on; the teaching method is computer-centered learning environment and individualized foreign languages learning but not the textbooks, blackboard and chalk; the teaching concept shifted to students-centered from teachers-centered that teachers control the classroom all the time; the textbooks are multi-dimensional but not the plane paper ones, the teaching contents are multimedia-centered; the teacher's role is to facilitate and help students actively construct knowledge but not only an interpreter or instructor; the teaching environment is not restricted to the classroom which lack the real language learning surroundings but create the web-based powerful one to learn and practice; the assessment is formative assessment but not the summative assessment which focus on the results of examinations. The following charts can best illustrate the changes from the traditional teaching mode to the integration of information technology into college English curriculum (An, 2008).

teachers $\longrightarrow$ teaching materials $\longrightarrow$ students

The above chart tells that the materials are the only resources of knowledge to the students.

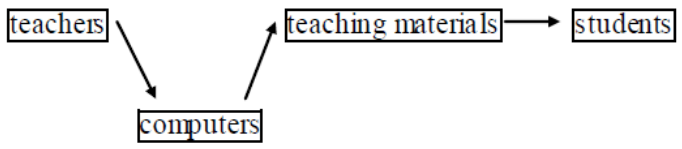

Although the employment of computers reinforces the effect of teaching, the resources of knowledge are still mainly from the teaching materials.

After the integration of information technology into curriculum, the traditional structure of teaching has been broken.

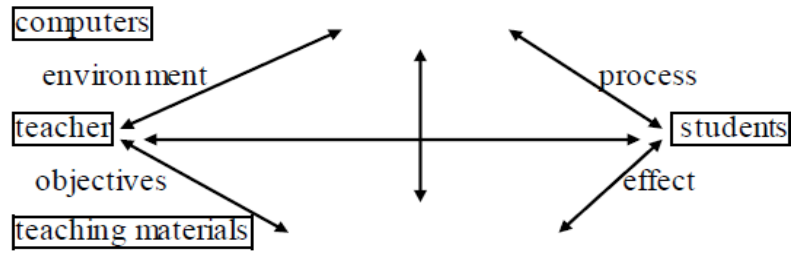

As far as the teaching materials are concerned, the relationships between teacher, students, and computer and teaching materials are not one-way but interactive ones.

The above changes inevitably damage the balance of the traditional ecological system of college English curriculum. The ecological theories bring us reflections and inspiration which concern how to take good advantage of the information technology and how to make the ecological system of college English curriculum back to balance. The following part will discuss the mode, development of teaching materials, teaching environment, teachers' role, assessment and mutual competitions of college English curriculum (Chen, 2005).

\section{A. Mode of the Curriculum}

Curriculum is the core of educational reform because any advanced educational concepts eventually influence the curriculum and the students. After information technology integrates into the college English curriculum, the curriculum itself should play an important role and interact with other factors (niches) to achieve the dynamic balance of the ecological system of the college English curriculum. 
The traditional curriculum was composed of theories, methods and teaching materials, while after integrating into information technology it is composed of theories, methods, technology and teaching materials, resources bank and netbased resources and so on. On the whole, the ecological mode of college English curriculum should center on the platform of college English curriculum and transfer the preparation of teachers, assignments of students, exams, questionand-answers to the campus network platform. Therefore, both the traditional teaching factors and the modern one coexist in harmony which can make them find the appropriate place in the ecological system of college English curriculum. Among which, the teaching materials, resources bank and the network resources change and update constantly which both the teachers and the students can upload resources. The students' initiation, practical ability and creativity can all be fully cultivated and brought into play (Wang, 2011).

The teaching mode based on computer and classroom involves the integration of classroom teaching and autonomous learning. The classroom teaching still is administrated by teachers and assisted by multimedia courseware; the students' autonomous learning is supported by network when teachers' role is organization and assistance. The subject status of students can be achieved and the leading role of teachers is not neglected. The main factors of teaching include students, teachers, administrators, resources and technology and so on. The teachers' leading role involves organizing the class efficiently and inspiring the students' motivation and initiation. Because of the intervention of the administrators, resources and technology, the chances are that the classroom teaching arise imbalance and rejection which involve the teachers are able to diagnose the reasons of imbalance and adjust accordingly. At this moment, the improvement of teachers' teaching techniques is indispensable.

\section{B. Development of Teaching Materials}

The teaching materials play a critical role which determines whether the integration of information technology into college English curriculum is successful or not because the teaching materials are the concrete embodiment of the integration. Meanwhile, it is also the important part for the achievement of curriculum objectives. However, the materials at hand cannot make the function of information technology be achieved fully and there is still some room to achieve the goal of Requirements. The mode of teacher-dominated has not changed; the multimedia courseware and network curriculum are just the extension of the plane paper textbooks.

At present, the reform of college English curriculum mainly involves the advanced teaching concepts, multidimensional teaching materials and modern teaching methods. In order to make the newly-appeared niche find the appropriate place in the ecological system of college English curriculum, the personnel of teaching material development and teachers are supposed to adjust the concept timely; the information technology has not been the assisted instrument but the important teaching factor which should integrate into the teaching materials. And the teaching materials are supposed to embody the characteristics of individualization and hypertext.

Besides, the development of teaching materials should integrate with both the syllabus and course objectives; take the learners' needs into consideration to facilitate the process of learning; various teaching methods should be employed to cultivate the students' comprehensive ability of language learning to avoid the imbalance of language ability and create the real language conditions for the students.

\section{Teaching Environment}

The ecological teaching environment of college English curriculum includes the software and hardware environment. The hardware environment is composed of electronic language lab and the construction of the public learning environment, while the software includes the staff, the web-based English learning environment, the humanistic learning environment, the creation and construction of the individualized teaching mode of college English curriculum which is based on computers.

The Requirements put forward that the new teaching mode is supposed to be supported by modern information technology, especially the network to make the teaching and learning of English cannot be restricted by time and place and make for the direction of individualization and autonomous learning... it contributes to stimulate both the teachers and students, especially embody the dominate position of the students and the leading role of teachers in the process of teaching. The classroom teaching can be extended by the English teaching based on computer and classroom after the integration of information technology into college English curriculum; there are suitable environment and condition for the autonomous learning and the development of individual, which contributes to the balance of the ecological system of college English curriculum. Student stands in the center of the ecological system of college English curriculum and all the design and application concerning teaching activities revolve around the development of students. The teachers should manage to create the peaceful and harmony relationship between them besides the comfortable and autonomous learning environment and the students-dominated teaching concept. The famous psychologist Rogers brought forward that the successful teaching depends on harmony and comfortable atmosphere of classroom. The harmony atmosphere of class is the important psychological condition which embodies the students' creation, the relationship between teacher and students is bound to influence directly the practice and effect of teaching.

In addition, the interaction between teacher and students is one of the often neglected factors after the integration. The traditional relationship between them is replaced by the interaction between human and computers which should be paid more attention by the teachers. 


\section{Teachers' Role}

The traditional role of teachers cannot interact positively with other niches in the ecological system of college English curriculum after the information technology integrated into the college English curriculum. It cannot accommodate the students' expectation to the teachers and the new teaching mode. The profession of teacher has long been regarded as one of the most authoritative ones; it is more expected with the development of teaching theories and methods. The information technology has outgrown the assistance in the college English curriculum and stepped forward to the foreground which requires the teachers' change accordingly with the teaching environment.

Under the circumstances of integration, the students expect teachers to create more active learning environment in class and offer equal opportunities for each one to make the students' knowledge and skill be fully brought into play which involves the teachers adjust on time.

As one of the most important niches in the ecological system of college English curriculum, teachers are supposed to be the organizers and assistants of classroom activities but not the keynote speakers; the researchers of classroom teaching but not the executors; the designers of future lives but not the instructors of knowledge acquisition; the constructors of knowledge system but not the transmitters of cultures (Wang, 2010).

One thing that is not supposed to be neglected is that the teachers need cultivate the accomplishment of informationteaching. Firstly, teachers should possess the ability of appropriately employ the multi-dimensional teaching materials, teaching design and the development of teaching materials. Secondly, teachers are required to select the suitable resources and optimize combination when facing massive resources. Before class, teachers are the designers and developers of the curriculum; in the class, they are the lecturers, organizers, trainers and evaluators; after class, they are the assistants and the providers of resources.

\section{E. Assessments}

Although the summative assessment can inspect the students' performance to some degree, this assessment method which gives priority to the formation of language is not scientific and comprehensive. For some occasional factors, a test paper cannot fully embody the comprehensive performance of the students. This kind of single and fixed assessment method is a shackle not only to the traditional teaching mode but also to the integrated one. It is bound to influence the balance of the ecological system of the college English curriculum.

The curriculum concept of the college English deems that the development of students is moldable, it is necessary to provide the basic knowledge, skills and methods of life-long development to meet the ever-changing social needs. On the basis of the above reasons, college English should employ both the formative and summative assessments. Teachers can analyze the students from the micro-ecology perspective; pay more attention to the uniqueness of each student to make different niches obtain balanced attention so as to the distribution of resources make for a reasonable direction. The recommended forms of formative assessment include records of extra-class activities, learning performance in class and web-based autonomous learning which can be used to observe, monitor and assess the process of students to facilitate the students' learning (Li, 2011).

The teachers can also take advantage of the network to organize the students to make self-assessment which contributes to the teachers' monitoring and administrating to the whole process of learning. Aiming at certain software, the teachers can solve the problems by techniques to remove the "tumor" in the system.

\section{F. Mutual Competition}

The ecology holds that when a new species enters into the ecological system, the new species is bound to interact with one or more original species and the whole environment. The new species will compete for the survival resources with other species; therefore, all of them evolve on the long term. There exist competitions among and between the ecological systems of education. The competition is classified into positive competition and the negative one. (Ding, 2011). The positive competition refers to the study and stimulation based on the single objective and common interests by the means of endeavors, through which both can achieve accomplishment and improvement. However, the negative competition is on the opposite which id mostly destructive. After the information technology integrates into the college English curriculum, the forms of competition are competition in scientific research, competition among technologies and competition between teachers.

Among which, the competitions among technologies is supposed to be paid more attention. After the entering of information technology as a new species, it inevitably competes with the present species (the traditional teaching factors). In the class, the new technology and the traditional ones compete for the resources, it may cause that more attention is paid to the technologies by teachers and the class and influence the attention to the teaching contents. The negative effects are bound to emerge under the unsuitable competition between information technology in class and the traditional teaching methods. If the information technologies can cooperate and improve the teaching effect when competing, it may bring positive effects to the class.

Teachers are the main body of the application of the technologies, therefore, teacher plays a critical role and determines whether the applications of information technologies are suitable or not. The essence of technology competition determines how the teachers select technologies appropriately. The presentation of different information technologies compete, for example, the traditional multimedia teaching and other technologies compete with each other. They are in the same place in the ecological system, in order to be employed at their most there are bound to be 
competitions between them. The newly-introduced technology are bound to be neglected due to the teachers are unfamiliar with it when it is first introduced into the class. With more and more teachers begin to use this technology; the advantages of the new technology will appear gradually and bring the teachers' attention to it. The results of competition may lead to the survival of the fittest. Whether the new technology can stay or not is determined by the features of the technology and its adaptation to the surrounding environment. After the competition, the technologies which can meet the needs of the teaching can survive, while the others will fade gradually.

\section{Problems NeEding Attentions}

Teachers are required to pay more attention to the following questions in order to practice students-centered teaching mode and avoid the misunderstanding of that.

\section{A. Teacher-student Relationships}

In the traditional teacher-centered teaching mode, teachers are the controllers of the teaching process, designers and implementers of teaching activities. This traditional teaching mode has been common in China. However, more attention has been paid to the full play of the students' role nowadays. That is, under the new teaching circumstances, more efforts should be paid to the return of students' subject position. But in the practical teaching some teachers change the classroom of subject position return into the drift of class which weakens the teachers' role greatly. This trend of extremes is ubiquitous among the teachers who know little about information technologies or the structures of the new mode. Therefore, in the process of teaching some teachers let the students go as they want in the network-based autonomous learning but not monitor (Wang, 2010). Under such circumstances, the advantages of information technology cannot be fully brought into play and the fulfillment of the teaching activities in the traditional teaching. The necessary interaction between teachers and students and the personal charisma of teachers tend to be influenced to some degree. Teachers should pay more attention to the harmony of student-centered classroom and overcome the tendency of the over-emphasis to the autonomous learning. Undoubtedly, the emphasis of the subject position facilitates the creation of autonomous learning but cannot be overemphasized because college students haven't changed the modes of learning in middle school. Therefore, when more attention has been paid to the subject position of the students, teachers are supposed to bring the leading roles into play so as to the teaching structure of leading and subject develops in harmony.

\section{B. Ways of Knowledge Transmission}

Teachers are required to understand the ways of knowledge transmission in information age because the students receive information, remarks and solve problems in an untraditional way. The correct thinking mode of digital learning plays a vital role in their future development while the information is enormous and complicated, and some are even misleading which requires the teachers make efforts to cultivate the students' abilities of creation in the process of teaching and encourage the students to view things from the objective perspective associating with their original knowledge (Huang, 2009). It is impossible to bring the advantages of information technology into full play and create the environment of autonomous construction of knowledge if the teachers just input the knowledge all the time.

\section{Correct Understanding of Changes}

After the information technology integrated into the college English curriculum, the new teaching mode changed the simple and passive input of knowledge into the active construction of that.

The first change lies in the cultivation of objectives, which can be embodied by the shifts from knowledge-based education to the ability-based one. The multimedia-based education mode has great impact on the teaching materials of college English curriculum: the simple input of knowledge is replaced by the one which focus on the inter-association and combination of real life; the students can build the ability of problem solving and creative thinking by active exploration. The second one is about the changes in the ways of knowledge acquisition. In the traditional teaching mode, the students acquire knowledge by the passive and accepted way; the one-way input of teachers limit the creative thinking and the active construction of knowledge (Tan, 2009). The multimedia-based teaching mode change the traditional teaching concepts and methods, the students can accomplish all kinds of autonomous and cooperative learning and break through the restrictions of time and space so that the students can achieve success of learning by creating students-based learning environment and providing massive information resources. The last one is the shifts of learning mode, which refers to the students' autonomy but not the abstract learning strategies and methods. The basic feature is the organic combination of the involvement of students' behaviors, emotions, cognition and socialization. But pure behavior cannot facilitate the development of students' thinking ability; the active emotion experience and involvement of cognition are the essence of active learning modes. Therefore, the new learning mode changed the way of learning greatly; the students' learning does not merely depend on the instruction of teachers based on teaching materials but interactive learning based on information resources and cooperation between students and teachers.

\section{Discussion}

The integration of the information technology into the college English curriculum inevitably lead to the great changes in the information delivery, teaching contents, design of teaching activities and the form of integration of the traditional 
college English teaching. (Zhang, 2011). These changes are bound to make the relatively stable ecological system of college English curriculum change accordingly. In order to make the ecological system of college English curriculum back to balance after the integration of information technology and college English curriculum again, it is pressing and necessary to study the forms, methods and modes of integration.

On the whole, the practices of ecological teaching in college English classroom tend to have positive impact on the traditional college English teaching. Certainly, there are still many questions to be explored further, for example, how to improve the teachers' information accomplishment, how to improve the teaching management and coordination to the integration of teachers, etc. These questions to be resolved offer a clear orientation for the future study (Chen, 2010).

In addition, when taking good advantage of the information technology, teachers should inherit the goodness of the traditional teaching mode and bring the advantages of traditional college English teaching into full play at first.

\section{ACKNOWLEDGMENT}

I wish to thank Dan Wang for her valuable suggestions on earlier versions of this article. Thanks also to Xu Zhang for her constructive criticism. My thanks also go to Zheyuan Jia for his assistance in material collection. I especially thank my family and friends for their support.

\section{REFERENCES}

[1] Bo Huang. (2009). The Reflection of Ecological Teaching of College English. Education and Careers, 4, 100-102.

[2] Fangyuan Li. (2011). The Ecological Exploration into the College English Curriculum Based on computers and Networks. Computer-assisted Foreign Language Education, 8, 76-81.

[3] Jianlin Chen. (2004). The Theoretical and Applied Analysis of Net-based College English Teaching. Computer-assisted Foreign Language Education, 12, 44-47.

[4] Jianlin chen. (2004). Modern Foreign Language Teaching Research-Theories and Practice. Shanghai: Shanghai Foreign Languages Teaching Press.

[5] Jianlin Chen. (2005). The New Orientation of Computer-based Foreign Language Teaching-from Assistance to Dominaion. Computer-assisted Foreign Language Education, 8, 21-27.

[6] Jianlin chen and Zhizhong Gu. (2008). The New Interpration to the 2007 College English Curriculm Requirements. Computerassisted Foreign Language Education, 2, 43-48.

[7] Jianlin chen. (2010). The Integration of Information Technology into College English currilum-A Study Baased on the College English Teaching Reform. Shanghai: Shanghai Foreign Languages Teaching Press.

[8] Jing Zhao. (2009). The Ecological Teaching of College English Curriculum. Modern Education Sciences, 7, 63-64.

[9] Jingwei Ma. (2010). On Principal Factors Af fecting the Construction of Ecological College English Classroom. Journal of Lanzhou Jiaotong University, 4, 157-160.

[10] Li Zhang. (2011). The Sudy on the Mode of Ecological Teaching of College English. Scientific Information of Heilongiang, 7, 144.

[11] Ministry of Education. (2007). College English Curriculum Requirements. Shanghai: Shanghai Foreign Languages Teaching Press.

[12] Qi An. (2008). The Ecological Reflection on the Web-based College English Teaching. Beijing: Beijing Normal University Press.

[13] Wei Tan. (2009). On the Principles of Constructing Classroom Ecology for College English Teaching and Learning. Journal of PLA University of Foreign Languages ,5, 57-60.

[14] Xiaowei Wang. (2010). A Study on Ecological College English Teaching. Journal of Hubei TV University, 10, 131-133.

[15] Xiaoyan Ding. (2011). Approaches on Teaching Practices in the View of Eco- education. Journal of Jiyuan Vocational and Technical College, 9, 70-72.

[16] Yulan Wang. (2010). The Ecological Analysis of College English Curriculum. Journal of Zibo Normal College, 2, 41-43.

[17] Yulan Wang. (2011). The Ecologicalization of College English Curriculum. Journal of Suzhou Education Institute, 4, 124-125.

Xin Tang was born in Harbin, China in 1978. She received her Master's degree in linguistics in 2005. She is currently a lecturer in Beijing Institute of Petrochemical Technology, Beijing, China. Her research interests include information technology and language teaching.

Weiran Zhang was born in Henan, China in 1978. She received her Master's degree in English Language and Literature in 2002. She is currently an associate professor in Beijing Institute of Petrochemical Technology, Beijing, China. Her research interests include language teaching and translation studies. 